\title{
Engaging Tools for Dialogic Guidance in Higher Education
}

\author{
Randi Benedikte Brodersen \\ University of Bergen, Norway \\ Birger Solheim \\ University of Bergen, Norway \\ Pål Steiner \\ University of Bergen, Norway \\ Tina Torgersen Oftedal \\ University of Bergen, Norway
}

\begin{abstract}
In this article we present a toolbox for dialogic guidance that we use at the Academic Writing Centre at the University of Bergen when guiding students in various stages of the writing process. Our guidance is dialogic which means that we acknowledge that meaning and learning evolve when we interact with one another, when different and divergent voices meet; we let students themselves explore their writing, their writing processes and their texts, and find their own answers, their own solutions and their own ways. We ask open-ended questions, listen, describe and provide tools that meet different needs at different stages of the writing process, instead of judging and 'diagnosing' the written texts - and the students and then proposing a 'treatment'. Examples of our tools are spontaneous writing, the academic pentagon and the Toulmin model of argumentation. We seek to strengthen the students' understanding and awareness of their own writing, thereby improving not just the writing at hand, but also the students' academic writing skills and learning in general, and to develop a reflective and accepting attitude. Our students engage in dialogues with us, the tools we present, with themselves, their texts and their writing, with fellow students, with previous bachelor and master theses, and with the tradition which they are part of.
\end{abstract}

\section{Introduction}

'What kind of writing guidance best supports and assists students?' Variants of this question, as well as a multitude of different answers to it, are likely to occur to coordinators and tutors of writing centres, as they did to us when we opened the doors of the Academic Writing Centre at the Faculty of Humanities, at the University of Bergen in 2014. From the very beginning, it was clear to us that we wanted our writing centre to offer a dialogue-based alternative to traditional monologic writing guidance.

Despite the many pedagogical reform efforts during the past 40-50 years in Europe and the USA (Bazerman et al. 2005: 20), guidance practice at universities can still be described as mainly monologic. Many supervisors, it appears, still have difficulties finding an alternative to old habits when giving feedback on drafts (see 
2009; Nicol 2010). What many supervisors and tutors tend to do is primarily the following: we read the submitted draft, comment on what we think should be changed, take note of and mark errors, and maybe highlight a few positive aspects.

In this article, ${ }^{1}$ we first introduce and discuss dialogue-based guidance, focusing mainly on face-to-face sessions. We follow with a description of a set of tools that we find useful at our writing centre. The tools are used to respond to different issues at various stages in the process, but are all part of a toolbox from which students and tutors may pick and choose at any given moment in the writing process. Finally, we examine borderline situations between dialogue-based and monologue-based guidance.

\section{Dialogic guidance}

An alternative to the prevailing monologic approach is dialogic guidance. This is a sociocultural mode of guidance inspired from developments in educational psychology involving a dialogic approach to teaching and classroom-activities. These developments have had a significant impact in the past two decades. Educational psychologists call this the dialogic turn (e.g. Racionero and Padrós 2010).

Of course, dialogic practices are already routine at writing centres and in many offices. But rarely is dialogic practice explicitly and intentionally made the foundation of guidance. At our writing centre, a team of professional and peer tutors has developed, through dialogue, an understanding of how dialogic guidance can best benefit student writing in one-on-one guidance sessions and in writing workshops and seminars.

A dialogic approach is a well-known method in teaching and collective guidance (e.g. Brodersen 2009, 2015, Cramp 2011, Dysthe 1997, 2001, Dysthe, Bernhard and Esbjørn 2012, Nicol 2010), but its adaptation for one-on-one guidance is underdeveloped. Our dialogic approach is similar to Kenneth Bruffee's 'non-directive' tutoring (Bruffee 1988). Like Bruffee, we aim to assist writers to become members of the academic community, and some of the tools aiding us to do this can readily be described as non-directive, minimalist approaches to tutoring. On the other hand, we do not avoid directiveness at any cost; when directiveness fosters dialogue, we embrace it. As an example, in cases where students might be provoked into defending their views or certain aspects in their thesis only to be confronted with directive comments, we would prefer a dialogic approach. Dialogue is a broader approach than nondirectiveness.

Space constraints do not permit an exploration of the topic of dialogue and dialogism, but we want to acknowledge the researchers who have influenced and inspired our dialogic practice, in particular our approach to guidance as introduced, developed and practiced in Norway by pedagogue Olga Dysthe. Her writings draw upon Mikhail Bakhtin's (1895-1975) notions of dialogue and dialogism, implying that dialogic teaching - and, for us, also guidance - is 'based on a dialogic understanding of meaning and communication, where we take the consequences of the fact that meaning arises and is developed through interaction between people' (Dysthe, Bernhardt and Esbjørn 2012: 6). New meaning is created when diverging voices meet in a dialogue. For instance, students often encounter different voices in literary sources or in discussions with fellow students or supervisors and then need to discuss these to determine which they might use or adopt in their own work and how.

In addition, many of the tools we use in our dialogic guidance are adaptations of the tools developed by Lotte Rienecker and Peter Stray Jørgensen in The Good Paper: A Handbook for Writing Papers in Higher Education (2013) and by Peter Elbow in Writing Without

\footnotetext{
${ }^{1}$ This article is an elaborated version of the presentation held by Randi Benedikte Brodersen, Birger Solheim and Pål Steiner, University of Bergen, at the EATAW-conference at The University of Tallinn June 16, 2015. Tina Torgersen Oftedal worked as a tutor at the Academic Writing Centre at the Faculty of Humanities, at the University of Bergen, in the Autumn 2015.
} 
Teachers (1998a) and Writing With Power (1998b) to help writers take charge of their own texts. Besides which, we are inspired by Marshall Rosenberg's non-violent communication (see Brodersen 2013a, Rosenberg 2015). We wish to build on these foundations, seeking to adapt these tools in the dialogic practice of our writing centre.

\section{Dialogic guidance creates self-regulating learners}

As writing centre staff, we often have the opportunity to spend more time with writers than most supervisors and teachers; a trend that may be of increasing relevance in a time when institutional financial constraints and cutbacks may drive faculty away from face-to-face interaction with students (see Cramp 2011: 114f). We can utilise our unique situation at the writing centre to develop and practice our dialogic approach.

At our writing centre, we understand dialogic guidance as a situation in which the tutor enters into dialogue, actively listening to students, trying not to interrupt. We ask our students to describe what is going on in their texts and their choices in the texts, before we explain in a non-judgmental way what we observe and hear. This sets the stage for a dialogue about textual features, like composition, coherence and flow, the use of theory, methods and sources. We do not pronounce a 'diagnosis' on drafts, but assist and help the students to recognize how they can improve their text. In this way, dialogic guidance is an instrument by which tutors provide students with tools with which they can think, learn and write on their own.

While striving to encourage students to take full responsibility for their writing themselves, we aim for a genuine dialogic approach. If we imagine a scale with dialogic guidance in the middle and monologic guidance at both ends, with the student's monologic talk on the left and the tutor's on the right, as illustrated below, our techniques help us to place ourselves between the middle and the left end of the scale, letting the student lead the dialogue, when possible.

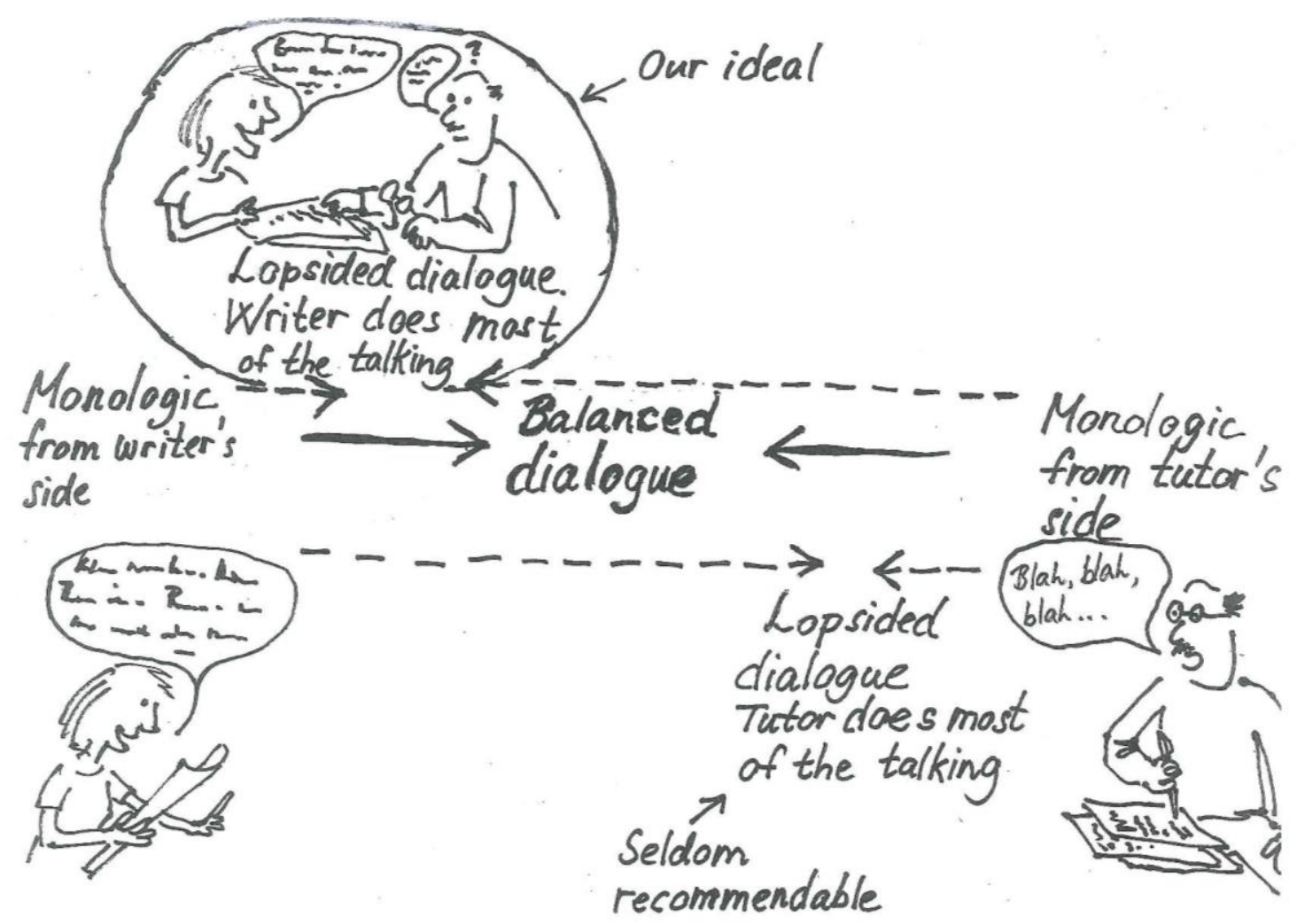

Figure 1. The continuum of dialogic and monologic guidance (drawn by Birger Solheim) 
In other words, guidance where a tutor speaks less than he or she is used to, and the student does a lot of, or even most of, the talking, corresponds with our ideal. We take the dialogic approach a step further by consciously shifting the traditional balance of power in the supervisory situation: the writers themselves become the main source of knowledge. Although this may be a valuable approach in most supervision sessions, it has an added value at a writing centre, because the tutor often has little prior knowledge or expertise on the domain of the subject. On their subjects, students are the real experts, while the tutor is an assistant. Consequently, dialogic writing guidance is characterized by a receptive and accepting attitude; the tutor keeps silent much longer than she or he is used to and leaves most of the talking to the writer but responds with body language showing dialogic engagement. In our experience, it is surprising how keenly writers can focus on their own, as long as they are given an opportunity to voice their challenges, 'problems', and thoughts to a listener.

Try this: How long are you as a writing coach able to keep quiet? How long can you wait for a response to an open question? Answer: Much longer than you think. This is an old journalistic trick: A journalist asks a question and holds the microphone in front of the interviewee until he or she starts talking. Students, like interviewees, feel that something needs to be said when the supervisor remains silent for a long while. Moreover, when they finally start talking, the knowledge they already possess and of which they become aware, is often surprising, as is their ability and their processes for identifying strengths and weaknesses in their own texts.

Finally, we want to remind ourselves that students are always the owners of their own texts. To accomplish this, we utilise a set of tools in our practice whereby we give the students tasks that encourage self-regulation, learning and reflection, usually followed by open-ended questions that facilitate a dialogue between tutors and students about the state and progression of the students' writing. Some of these tools we introduce in the following.

\section{A hiking trip through the writing process: seven tools for dialogic guidance}

Our receptive and observational attitude outlined above is an important starting point in guiding the students through the writing process, which we visualize as a mountain trek across the seven mountains surrounding the city of Bergen, as shown below. The hike consists of deep valleys and steep inclines, representing challenges in the writing process. As writing tutors, we usually provide guidance to students when they are down in a valley with a steep hill ahead. Each incline can be surmounted with the help of a suitable tool in the tutor's toolkit. Fortunately, the hike also has peaks where students can celebrate the fruits of their hard work, and a number of descents, where writing flows easily and freely.

Of course, this hiking trip reflects an ideal writing process. In reality, the writing process is recursive, not unlike the board game Chutes and Ladders. Therefore, it is vital that our students learn to safeguard their tools. What they learn climbing the first hills, they tuck away in their rucksack, ready to be used on any of the inclines ahead.

Our supportive interaction has a cumulative effect, and the different tools are available at different stages as the hike progresses. 


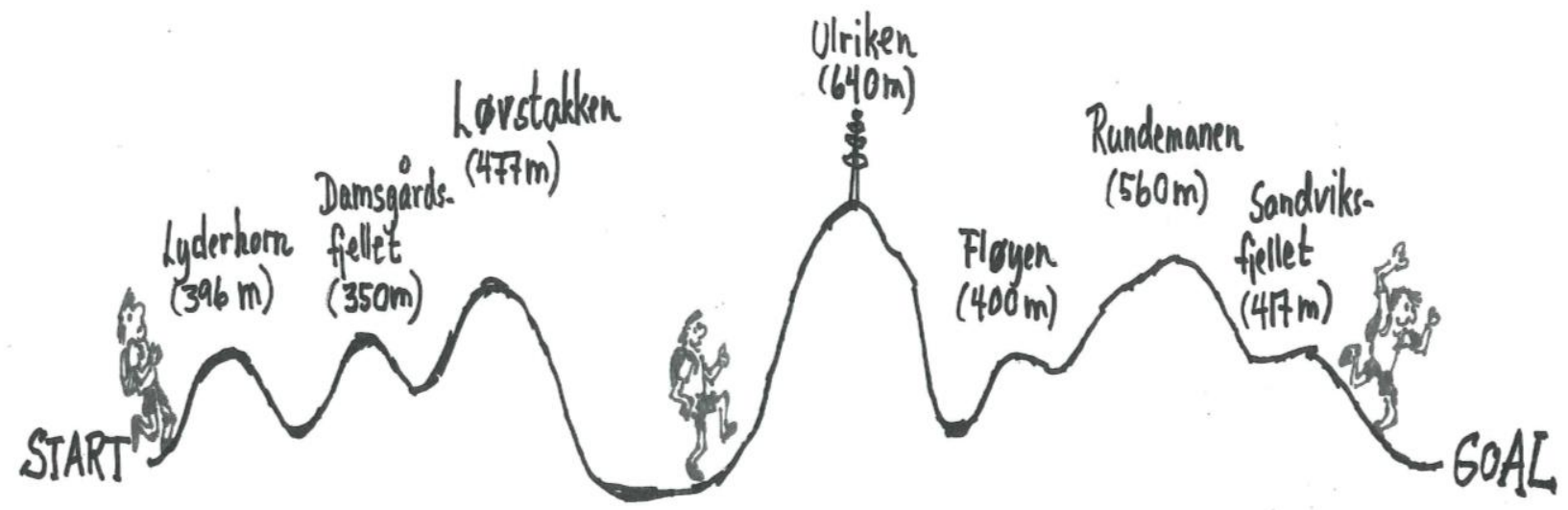

Figure 2. The seven mountains in Bergen representing a student's hike through the writing process (drawn by Birger Solheim)

To climb each hill during our trek, we need to use different strategies to coach and assist our students in overcoming the different challenges that might occur. Therefore, we list seven ideas and tools that we have experienced as valuable and useful for dialogic guidance at various stages of our students' writing process. Each hill represents a challenge, each tool a climbing aid. In the following, we offer an example of each challenge, followed by an explanation of applicable tools.

- Mount Lyderhorn: Identifying the topic and subtopics Tool 1: Spontaneous writing as part of dialogic guidance with open-ended-questions

- Mount Damsgård: Getting a grasp of the task at hand Tool 2: The academic pentagon

- Mount Løvstakken: Planning ahead Tool 3: Formulate a plan for further reading and writing

- Mount Ulriken: Composition, intelligibility, and sources Tool 4: Criterion-based guidance

- Mount Fløyen: Argumentation Tool 5: The believing game

- Mount Rundemanen: Finishing on time, writing academically Tool 6: Roleplay using a personae technique

- Mount Sandviken: Checking your arguments Tool 7: The doubting game

Mount Lyderhorn: Identifying - or finding - the topic and subtopics.

Anne is writing her research proposal for a master thesis on two stories by writer Karen Blixen. Early in the semester, she visits our writing centre for guidance. Thus far, Anne has read a lot, but she wonders if and how she can apply it all in her project proposal. There are many ideas occurring in Anne's mind. She finds it difficult to structure her thoughts and develop her theme.

Tool 1: Spontaneous writing in combination with open-ended questions.

Anne needs to sharpen her focus and find a direction in her writing. A useful tool to this end may be spontaneous writing, a free writing technique (Brodersen 2013b and cf. Boice and 
Meyers 1986, Elbow 1992, 1998a), as a way to refine and develop her project. The student writes freely, spontaneously, creatively and maybe associatively - on an idea, a subject, a question for five to ten minutes and gradually longer, maybe even half an hour. This can be done without stopping, without changing and correcting things in the text, without thinking about spelling and formal details, without allowing one's own self-critical voice to interrupt or disturb. If words fail, and the student does not know what to write, then she might write just: 'I don't know what to write now, but I just will continue and see what happens...' (Brodersen 2013b). In this way, the writing opens the mind to all kind of thoughts, ideas and words that come to her. The receiver of the spontaneous text is, first, the writer herself, and secondly, whomever the writer might choose to share the text with, for instance, by letting someone read it or by reading it aloud or letting someone else read it aloud in a group.

Although spontaneous writing might be regarded as a prewriting technique, it can be applied at all stages of the writing process. It might also be used as a kind of brainstorming exercise to identify ideas or topics, or just to warm up before writing on a thesis chapter or a paper, or before entering a discussion. It can also be used to summarize an article or a discussion, to explore what to do next, or what one knows and does not know about a particular subject. It may also be useful for identifying keywords for literature searches. Of course, spontaneous writing mostly produces a draft or a reflective piece of writing, and it will frequently be necessary to rewrite it. In any case, we have often been impressed with the fluency and originality of what results from using this technique.

In Anne's case, the spontaneous writing technique is used as a method by which to develop and define ideas, thoughts, focus, and direction.

\section{Mount Damsgård: Getting a grasp of the task at hand.}

Kari is writing her bachelor's thesis in religious studies, and is particularly interested in how religions are portrayed in the media. She has limited the topic to an investigation of how Judaism and Islam are portrayed in Norwegian newspapers. Nevertheless, she still has concerns about how she could proceed from the chosen theme. She wonders if the topic is still too broad, and where to even begin.

\section{Tool 2: The academic pentagon}

Students having difficulties in starting writing will often benefit greatly from clarifying the research question and tools needed to complete the assignment on time. The most crucial task is perhaps to get an overall grasp of the assignment. Research questions are sometimes loosely delimited, leading students into a maze of literature and possible avenues of research.

Kari needs to find a way to focus her approach by closing broad avenues and avoiding dead ends. Before she commences a literature search and reading, she may profit from writing out a project description, using spontaneous writing at each of the five questions in the academic pentagon below, and at a later point, she may redevelop the project description into an introductory chapter. This may help her to approach her research in a methodical and planned way, making her further writing, literature search, and reading effective and efficient.

The academic pentagon described by Rienecker and Jørgensen in The Good Paper (2013), works under the premise that most undergraduate and graduate papers are structured around a few key elements that they have in common with traditional academic journal articles. Although requirements and expectations regarding the content of the corners of the pentagon do vary between fields and levels, all students will benefit from having a clear understanding of academic norms and standards.

In a tutoring session, the tutor can give the student a pentagon form with the five corners and questions below. Each corner of the pentagon may be seen as an individual task of spontaneous writing, as described under the first 'hill', followed by a discussion between tutor and student regarding the advantages and challenges revealed. Once 'completed', the pentagon form may prove to be a useful tool throughout the writing process, and when developing the paper structure and planning literature searches, because it clearly outlines the main parts of the paper. 


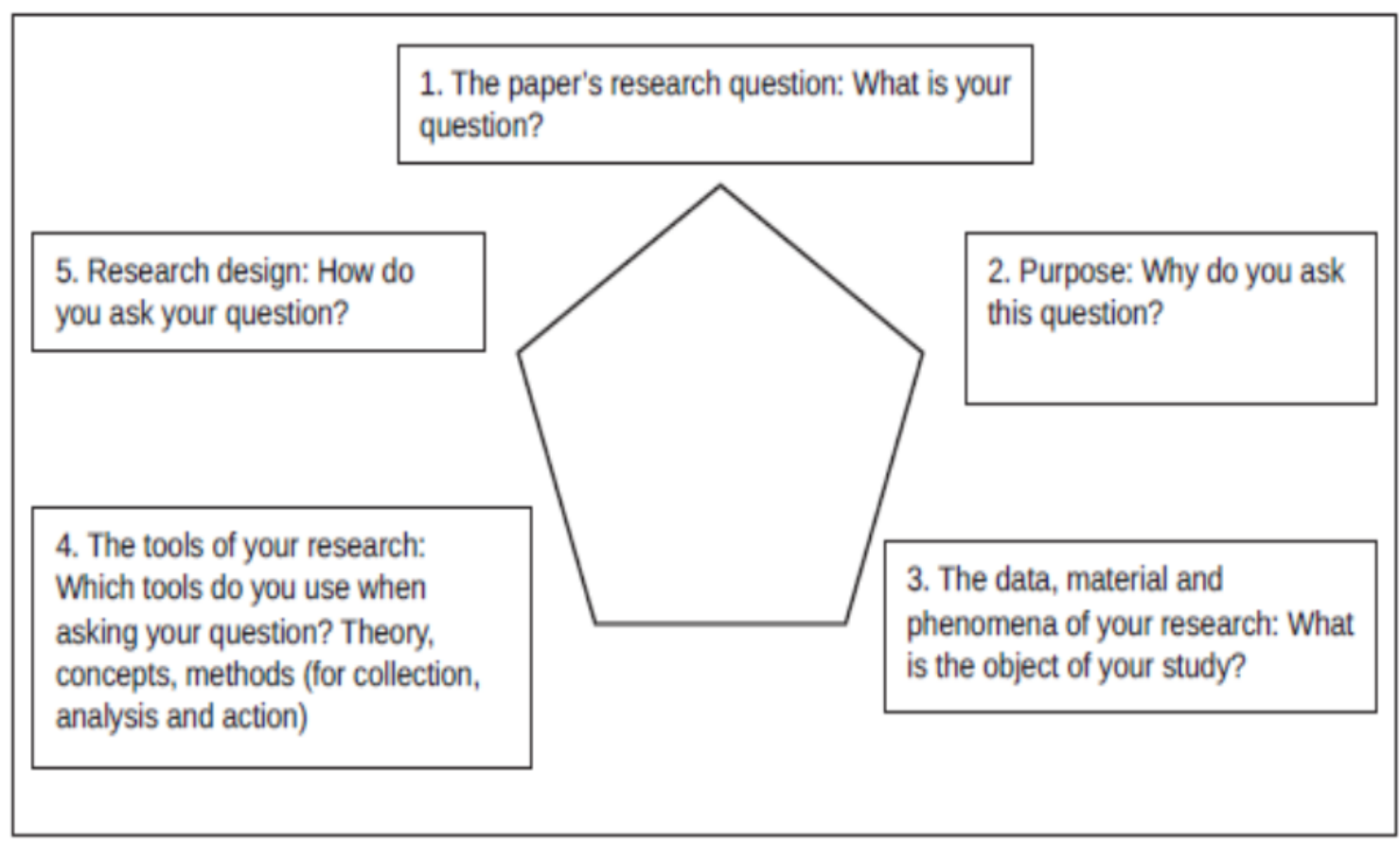

Figure 3. The academic pentagon (Rienecker and Jørgensen 2013; reprinted with permission)

Corner 1. Research question

Developing a research question is arguably a very significant part of the writing process. It is the platform that supports all subsequent decisions. In the early stages of research, the question is frequently underdeveloped. Thus, the purpose of filling in the pentagon form initially is to explore the research question and to develop it into a stable platform for a project.

\section{Corner 2. Purpose}

In the second corner, 'Purpose', many students tend to focus on the own subjective interests, and that may be an obvious and convenient point of departure. However, here the tutor might ask questions stressing that the main aim is to place the study within the context of a scholarly discourse on the topic. For example: why is this investigation relevant for your subject? How does your work build on that of others? Depending on the student's knowledge of the field and the subject, these questions may not be possible to answer before the student has conducted an initial literature search and read some main works on the field. The answers may provide both the student and the tutor with an impression of the student's familiarity with the topic, and thereby the expected workload and feasibility of the proposed research.

Corner 3. Data, materials and phenomena

Consultation of sources differs greatly, of course, between subjects. Some subjects require students to collect and discuss empirical data at the bachelor's degree level, while others expect the thesis to be built around a qualified discussion and consultation of secondary literature. Here, students need to be aware of, and know, the subject-specific requirements before considering their information needs in terms of the research question, and before exploring the availability of the sources.

Corner 4. Theories, concepts and methods

Clarification of the key concepts, methods, and theoretical ramifications of the research helps to distinguish a student's proposed work from that of others, thereby setting the stage for a productive debate with secondary literature. 
Corner 5. Research design or composition

Planning a temporary outline of the paper will help to organise the progression of the writing and research process. It enables the student to focus on one section at a time, and facilitates a common understanding of the structure between the writer, tutor and supervisor.

\section{Mount Løvstakken: Planning ahead.}

Erik has booked an appointment at the writing centre. He writes that he constantly 'struggles' with all his writing tasks. He often 'struggles' with composition and writer's block. He laments: 'It stresses me out, and I very rarely hand in the finished product'. For this home assignment, due in a week, he would like to receive help from a tutor, but he is not able to write anything before his first appointment.

Tool 3: Formulate a plan for further writing and reading.

Erik says that he is 'struggling' with all his writing tasks. He is uncertain about how to arrange his writing as there are so many elements to take into account. This leads him to procrastinate. One way to tackle such matters may be to engage in a dialogue with the student, for instance about previous writing experiences and maybe also about useful study techniques and working habits. Already before Erik's appointment at the writing centre, he has taken a great step forward. Not only has he become aware of his difficulties, but he has also reached out for assistance. The tutor can assist Erik in formulating a plan to help him organize his time and writing. If Erik has difficulties defining his task or formulating a research question, he could start out with spontaneous writing in combination with the pentagon form, as described above.

More importantly, it might be useful for Erik to organize and plan his writing tasks by identifying subtasks. Rienecker and Jørgensen propose that the student fill out a form, writing down subtasks and the time that may be devoted to each subtask (2013: 102-104). They give examples of such forms, with the task subdivided according to the time a student has available - a day, a few days, or a week. It includes subtasks such as interpreting the assignment question, brainstorming, gaining an overview, reading, writing, and revising. Writing centres could have such forms on hand, including an example of a filled-out form.

Another way may be to ask students to write a bullet-list of what they think they may accomplish each day until their papers are to be submitted. The list may become more and more detailed: First, a time schedule is set up for the coming week dealing with the most important elements of the assignment. Next, a more detailed plan for subtasks to be concluded each day, or even within a few hours of each day. The actual organization could be done largely by the students themselves, as only they will know their working habits, time schedule and how these may be manipulated. The tutor may assist by overseeing the task, making sure that the planning is feasible and that the writing and study-tasks follow a realistic progression.

\section{Mount Ulriken: Composition, intelligibility, and sources.}

Lars is currently working on one of his first academic texts. The deadline is in two weeks, and he has written more words than are allowed by the requirement, but he feels that he lacks coherence and structure within and between paragraphs. The tutor received his text a couple of days in advance and notes that no sources are used in the text.

\section{Tool 4: Criterion-based guidance}

In many guidance situations where the writer has already produced an amount of text, it is beneficial to focus on more specific criteria in the text, such as structure, intelligibility and sources (c.f. Elbow 1998: 241; Dysthe et al. 2010; Rienecker and Jørgensen 2013: 39ff). This is traditional also within monologue-oriented guidance. So how can we make the guidance at this stage dialogic, allowing Lars himself to discover a good way to structure his text?

Here a dialogic approach may be to have the student read his own text (either aloud or silently), followed by asking open-ended questions, for instance: 'What did you experience 
when reading your text? What is the structure like? Can you try to describe it?' By responding to these questions, Lars will reflect on his text, and it might be easier for him to notice whether some sentences and paragraphs are interrelated. In addition, depending on the results of the dialoque, it may be useful to ask Lars to study a previous bachelor's thesis and to look at that together as a kind of model text and then ask Lars to describe the structure in that text.

This can be followed up by proposing that Lars writes a short note behind each paragraph in his own text, in which he explains the purpose of each section, asking how the paragraphs fit together and if any of them are superfluous, or if one is missing. It may be followed by questions such as: 'Is the order logical? How does the composition work as a whole?'. Lars might then identify a logical way to structure his text himself.

A similar approach may be used with questions about the use of sources. Here the tutor may ask: 'Where do you use sources? Where don't you use sources? Is this thought or sentence your own, or have you read this somewhere?'. We always try to describe our observations, pose questions and promote insight. We try to avoid judging or expressing statements about the students' texts that might be interpreted as criticism.

During the dialogue, Lars will probably become aware of the individual elements of structure of an academic paper and of how sources are used. For instance, he might observe that in the text he starts to discuss the topic before presenting or defining important concepts. When Lars looks at his text together with the tutor and describes the use of sources, he might even see what needs to be changed and rewritten. The benefits of this approach are huge: pieces of the puzzle begin to fall into place in the writer's mind.

\section{Mount Fløyen: Argumentation}

Ingrid is writing a thesis in theatre studies. She has produced quite a bit of text and says that she is in control of the structure. However, the supervisor notices that Ingrid actually reproduces and describes the subject matter. She does not seem in charge of her own text.

\section{Tool 5: The believing game}

The tutor asks Ingrid where and how she discusses her research question. Then Ingrid suddenly notes that she has not yet included a discussion, and asks the tutor if there is a good way of doing this. The tutor proposes a method by Peter Elbow (1998a, 2008) called the believing game. This can be seen in the context of the doubting game, which is introduced here under the seventh 'hill' below. The believing game focuses on believing in the statements a writer uses in her text. It is based on finding new ideas and creative solutions instead of criticizing existing ideas (Elbow 2008:1). This might be the first step of adding a discussion part in Ingrid's thesis. Afterwards she can use the doubting game in the process to strengthen her arguments even more - Peter Elbow encourages using both tools as they complement each other.

When we put forward a claim, we actually have to believe in it: 'Often we cannot see what's good in someone else's idea (or in our own!) till we work at believing it" (Elbow 2008: 1). This means that we have to allow ourselves to find arguments supporting our claim without being immediately critical. We write the arguments down on our paper; we try them out. For example, how much can Ingrid find that actually supports the statement in the text when being asked?

A well-known model for composing arguments comes from British philosopher Stephen Toulmin. In his book The Uses of Argument (2008: 87) he describes "The Layout of Arguments" where an argument contains a claim (C) with data (D) and warrant (W) ${ }^{2}$ :

\footnotetext{
${ }^{2}$ «Warrant» is a juridical term that means 'justification'.
} 
Smoke is coming up from behind the mountain (D)
Smoke is coming up from behind the mountain (D)<smiles>[GeH3]</smiles>

No smoke without fire

Figure 4. Our adaption of the Toulmin Model (Cf. Toulmin 2008). (Toulmin 2008: 87).

This model is often used to enhance 'critical thinking', but it can also be applied in situations in which you want to keep formal critiquing at a distance for a while. Then you play the 'believing game'.

Because Ingrid has made no claim yet, the focus of the tutoring session is to encourage her to identify a claim by asking questions about the task or her theory that can trigger this, after having presented the model above. Questions the tutor might ask include: 'What do you find interesting in your paper? Do you have an idea for how you can answer your research question? How could you support your idea and make it into a claim?' This might inspire Ingrid to come up with new ideas. The tutor might propose that she writes down one or two statements that function as claims and then some arguments or data that can directly support one of the claims, or both, letting the data begin with 'because'. By doing this with different statements in her own text, Ingrid will become aware of her own argumentation.

Another way to make Ingrid aware of arguments in the text is to have a look at a model text together, analysing the explicit argumentation by finding a claim and data for the claim. Then Ingrid can continue adopting the structure of the argumentation to her own text.

\section{Mount Rundemanen: Finishing on time and writing academically.}

Svein and Jens arrive at the writing centre together. Svein is working on a short assignment and has completed a few paragraphs. Now, however, his writing has stopped. He wonders whether his language is 'too informal'; 'how do I write like an academic?', he asks. A fellow student, Jens, explains that he is also 'struggling' with a writing block. His challenge is that he is unable to come up with creative ideas on how to proceed with his analysis. He cannot identify new and interesting perspectives on his material.

Tool 6: Role play using a personae (mask) technique - in writing

Although spontaneous writing could be one way to approach these issues, the tutor suggests that role playing may help the flow of creativity. The tutor asks the two students if they would like to do a type of role play where one imagines that he is a productive and skilled scholar and an expert on academic writing who knows how to deal with time challenges and writer's block and has exactly the solutions one wants and needs. The other student plays an (inner) critic. By using such a personae technique, you choose a persona, a mask, that makes it possible to address your problems. Svein and Jens are puzzled! A role play and masks! They nod in agreement: Why not! Jens chooses to be the scholar, and Svein the (inner) critic.

The tutor briefly introduces the role play, highlighting three essential elements for the students: a) You choose a relevant persona, and you are the chosen persona who is capable of doing what you need to do. That means that you have the qualifications and abilities you need as that persona; b) You feel and internalize that you have exactly the qualities of your persona; c) You are and act like your persona - in writing (Skjoldborg 2009).

After a few minutes to take on the chosen persona, the inner critic writes many criticisms of Svein's text, and the scholar examines and describes how to finish Jens' text in time, using 
spontaneous writing for ten minutes. The scholar writes some solutions on how to deal with the time challenge by inventing a setting that promotes and inspires writing. The students read their personae-texts aloud to each other. By writing in this way, they have arrived at some concrete ideas on how to get on with their writing.

Role play using a personae technique - or individual use of the personae technique - with the solutions needed, might be a useful tool for guidance in several ways. Firstly, it is a tool that requires students to handle their own problems and find their own answers and solutions, while at the same time being creative and inventive. Secondly, a role play is a very free way of presenting problems and solutions. In the third place, there are no limits to the types of personae you can create within you, helping you to solve what needs to be solved.

\section{Mount Sandviksfjellet: Checking your arguments}

Lene is writing a term paper on rhetoric. The theme of the thesis is the prime minister's speech on New Year's Eve. She wants guidance on the arguments in her text. Lene knows much about rhetoric, but she is not sure to what extent her text will be perceived as persuasive. The tutor notices that Lene has largely pro-arguments for her case.

\section{Tool 7: The doubting game}

To assist Lene to become persuasive, the tutor proposes to use counterarguments. Keeping the dialogic approach in mind, the tutor chooses another strategy: first, the tutor decides to focus on explaining how counterarguments work, and to do so he refers to the Toulmin model, which we have introduced under the fifth 'hill'. As a student of rhetoric, Lene is already well acquainted with the model. By presenting and discussing some ready-made examples of how counterarguments can attack claims, data and warrants, the tutor assists Lene to develop her critical thinking skills, which she can apply directly in her text. She has already played the 'believing game' and found sustainable, relevant arguments for her claims. Now it is time to play what Peter Elbow (1998a; 2008) calls the 'Doubting game'.

Some tasks that a student can be given in the doubting game are:

1) Try to find as many arguments against your main claim or someone else's main claims or statements as possible.

2) Take a critical look at your data, and check whether you can find arguments against both the durability or credibility and the relevance of these data.

3) Find a partner or start a writing group together with fellow students. Decide to spend time explicitly focusing on finding counterarguments in each other's texts.

\section{Conclusive discussion: Negotiating ideal and actual practice}

To summarise, all the tools we have presented above, are designed and combined to support dialogic writing guidance. We actively seek to get rid of old monologic thinking habits and of all judgemental attitudes and statements. We know we cannot control the writing and meaning construction processes of our students. Meaning necessarily develops in every individual as new information or knowledge establishes relations with an already existing horizon of knowledge and experience.

At the same time, we try to rid ourselves of the old habit of always looking for deficiencies and 'errors' in the texts we read. We aspire to replace our corrective mode with a descriptive mode. In other words, we want to give writers the opportunity to describe their own texts by asking real questions such as: 'what is going on here? What is your aim with this paragraph? What would happen if you add some argumentation her? Or some examples?' We want to accustom ourselves to the habit of giving writing guidance using an open question-answer strategy. We want to ask open-ended questions and - importantly - listen to the answers the writers give. That is to say, really listen and hear (cf. Bruffee 1988), not just pretend that we are listening while we are planning ahead. 
A dialogic approach requires two equal partners, but, as we have seen, the techniques we have proposed above sometimes enhance a dialogue with a partly lopsided balance. Our ideal tutor acts like a facilitator. In this way, we try to stimulate writers to take responsibility for their own writing and process, their own text, and their own learning.

We have to admit, however, that reality and our ideal world sometimes do not meet. The kinds of dialogue that actually take place at our writing centre sometimes have less dialogic character than we intend. There are several reasons for this, but the most important one is probably that we still need practice in finding and using tools like those we have described above. In addition, given that dialogical counselling may be a slow process that takes more time than giving plain instructions, it may at times be difficult for the tutor to refrain from simply giving an answer or a solution when it is obvious and time is short. If the deadline is in a very short time, and occasionally students visit us in a panic because they have to submit an assignment within a few hours, we may have to choose fewer dialogic strategies. It is our conviction, however, that almost every challenge connected to writing guidance can be solved in a dialogic manner. Yet, we want to share with you two recurring situations that seem to make dialogic writing guidance challenging.

Sometimes we meet students who obviously find it challenging to handle a writing consultation with a tutor who invites them to a dialogue based on equality. Some students seem to have clearly pre-determined expectations that a writing consultation should be a kind of one-way communication where they receive high-quality information. But mostly, when we present our dialogic strategies, they seem to understand the value of these strategies. However, sometimes we experience that steps we normally suggest do not work, and we have to look for other possible solutions.

The receptive and accepting attitude, which we have proposed, might not suit everyone at first. Sometimes we are visited by students who seem to be triggered by resistance, who enjoy the intellectual duel that unfolds in an academic discussion. These students can handle being challenged and refuted, and being direct may even be appropriate to serve the students' specific suggestions for improvements. Why so? These kind of students do not necessarily accept suggestions as 'directives', but are instead encouraged by them to defend their own texts, elaborate on what they have been trying to say, and, in this way, improve their own drafts.

The list of tools that we have presented is not meant to be exhaustive. The main goal is to illustrate how dialogic guidance can be enhanced through well-designed tasks. The mere use of the tools, however, is not enough to make the guidance dialogic. The most important aspect of dialogic guidance is that the tutors develop an accepting, receptive, and nonjudgemental attitude that is based on a conviction that the best way to assist students is to interact with them, to help them help themselves. The relationship between writer and tutor that we propose is very similar to the relationship between a swimmer and his or her coach. A good coach presents his favourite swimming drills and exercises, taking the actual technique and even the personality of the swimmer into consideration. The best training programme is probably one that coach and swimmer develop together. In the same way, the skilled tutor uses his or her knowledge to facilitate the writing and learning process in dialogue with the actual writer.

We hope that this article will motivate tutors, supervisors, teachers and others who work with writers to take some steps towards adopting a dialogic and non-judgemental approach to writing guidance. To acquire this, however, requires practice, patience, and a lot of listening. Especially when time is short, when students are lining up outside your door and the student you are currently tutoring seems to be a little unreceptive, it is easy to give up and instead fall back on the old, routine patterns. Never give up! Keep up the effort! The more often you get a positive experience from the effectiveness of dialogic guidance, the easier it is to practice this approach, even with short time constraints. 


\section{References}

Bazerman, C., Little, J., Bethel, L., Chavkin, T., Fouquette, D., and Garufis, J. (2005) Reference Guide to Writing Across the Curriculum [online] West Lafayette, Indiana: Parlor Press. available from <http://wac.colostate.edu/books/bazerman_wac $>$ [25 January 2016]

Boice, R. (1994) How Writers Journey to Comfort and Fluency. A Psychological Adventure. Westport: Praeger Publishers

Boice, R. and Meyers, P. E. (1986) 'Two parallel traditions: Automatic writing and free writing'. Written Communication [online] 3, 471-490. available from <http://wcx.sagepub.com/content/3/4/471> [25 January 2016]

Brodersen, R.B. (2015) 'Dialogisk tilbagemelding på opgaver i academia'. In 14. Møde om Udforskningen af Dansk Sprog Aarhus Universitet 9. -10-oktober 2014 [online]. ed. by Schoonderbeek, I., Hansen, I.S. and Hougaard, T. T. Aarhus: Aarhus Universitet, 69-82. available from <http://muds.dk/rapporter.html> [in: MUDS 14] [25 January 2016]

Brodersen, R.B. (2013a) 'Kontaktskabende kommunikation: fra iagttagelser og følelser til behov og anmodninger'. in Gode ord er bedre end guld. Festskrift til Henrik Jørgensen [online]. ed. by Borchmann, S., Hougaard, T. T., Hansen, I. S., Togeby, O., and Widell, P. Aarhus: Aarhus Universitet, 111-131. available from $<$ http://ivk.no/artikler/ http://ivk.no/artikler> [25 January 2016]

Brodersen, R. B. (2013b) 'Spontanskrivning - og hurtigskrivning eller nonstop-skrivning i akademia. Hvordan, hvorfor og hvornår?'. in 13. Møde om Udforskningen af Dansk Sprog Aarhus Universitet 11. -12-oktober 2013 [online]. ed. by Schoonderbeek, I., Hansen, I.S., Hougaard, T. T., and Widell, P. Aarhus: Aarhus Universitet, 77-117. available from <http://muds.dk/rapporter.html> [in: MUDS 13] [25 January 2016]

Brodersen, R. B. (2009) 'Akademisk skrivning og vejledning - for vejledere og studerende. Mere kollektiv og dialogisk vejledning giver mere læring og flere gode opgaver'. in Milli mála. Ársrit Stofnunar Vigdísar Finnbogadóttur í erlendum tungumálum. ed. by M. Sigurðsson and R. prainsdóttir. Reykjavík: Háskóla Íslands, 173-217

Bruffee, K. A. (1988) 'On Not Listening in Order to Hear: Collaborative Learning and the Rewards of Classroom Research'. Journal of Basic Writing 7 (1), 3-12

Cramp, A. (2011) ‘Developing First-year Engagement with Written Feedback Active Learning'. Higher Education 12, 113-124. doi:10.1177/1469787411402484

Dysthe, O. (1997) 'Skriving sett i lys av dialogisme. Teoretisk bakgrunn og konsekvensar for undervisning'. in Skriveteorier og skolepraksis. ed. by Evensen, L. S., Sigfred, L., and Løkensgard Hoel, T. Oslo: LNU/Cappelen, 45-77

Dysthe, O. ed. (2001) Dialog, samspil og læring. Oslo: Abstrakt

Dysthe, O., F. Hertzberg and T. L. Hoel (2010) Skrive for å lære. Skriving i høyere utdanning. $2^{\text {nd }}$ edn. Oslo: Abstrakt

Dysthe, O., N, Bernhardt and L. Esbjørn (2012) Dialogbasert undervisning. Kunstmuseet som læringsrom, Oslo: Fagbokforlaget

Elbow, P. (2010a) '7. Freewriting: An Obvious and Easy Way to Speak onto the Page': $<$ http://works.bepress.com/peter_elbow/31> [25 January 2016] 
Elbow, P. (2010b) '11. Revising by Reading Aloud. What the Mouth and Ear Know': $<$ http://works.bepress.com/peter_elbow/33> [25 January 2016]

Elbow, P. (2010c) '12. How Does Reading Aloud Improve Writing': <http://works.bepress.com/peter_elbow/34> [25 January 2016]

andandElbow, P. (1998a) Writing without Teachers. $2^{\text {nd }}$ edn. New York: Oxford University Press

Elbow, P. (1998b) Writing with Power. $2^{\text {nd }}$ edn. New York: Oxford University Press

Elbow, P. (1992) 'Freewriting and the Problem of Wheat and Tares'. in Writing and Publishing for Academic Authors. ed. by Moxley, J. M., and Taylor, T. Oxford: Rowman and Littlefield Publishers, 35-48.

Hattie, J. and H. Timperley (2007) 'The Power of Feedback'. Review of Educational Research [online] 77 (1), 81-112. available from <www.jstor.org/stable/4624888> [25 January 2016]

Nicol, D. (2010) 'From Monologue to Dialogue: Improving Written Feedback Processes in Mass Higher Education'. Assessment and Evaluation in Higher Education [online] 35 (5), 501-517. available from

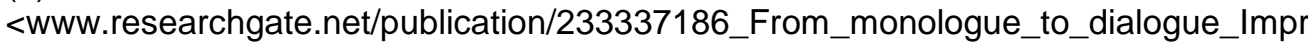
oving_written_feedback_processes_in_mass_higher_education> [25 January 2016]

Racionero, S. and Padrós, M. (2010) 'The Dialogic Turn in Educational Psychology'. Revista de sicodidáctica [online] 15 (2), 143-162. avaliable from $<$ www.redalyc.org/articulo.oa?id=17517246001 $>$ [26 January 2016]

Rosenberg, M. B. (2015) Nonviolent Communication. A Language of Compassion. $3^{\text {nd }}$ edn. Encinitas, CA: PuddleDancer Press. available from $<$ http://nonviolentcommunication.com/store/nonviolent-communication-language-lifeebook-p-168.html> [25 January 2016]

Rienecker, L. and Jørgensen, P. S. (2013) The Good Paper. A Handbook for Writing Papers in Higher Education.

Skjoldborg, B. (2009). Flow skrivning. Vejen til flydende skriveprocesser. Copenhagen: Gyldendal

Toulmin, S. (2008) The Uses of Argument. Cambridge: Cambridge University Press 